\title{
Benefits and Aura of Rubies and its Local Intelligence among the Malays Community
}

\author{
Noor Azam Azmi ${ }^{1}$, Kai Xin Tay ${ }^{2}$, Badaruddin Mohamed ${ }^{3}$ \& Salasiah Che Lah ${ }^{4}$ \\ ${ }^{123}$ School of Housing, Building \& Planning, Universiti Sains Malaysia \\ ${ }^{4}$ School of Humanities,Universiti Sains Malaysia
}

\begin{abstract}
Rubies are associated with aura and nutrients. Many scientifically researches have been carried out for examining the rubies as materials, however, the little-existed literature on beliefs and usefulness of rubies, especially Malay community who have used Rubies for many decades. Therefore, this paper is to critically review the benefits and aura of rubies from Malay local intelligence. This paper found that the Malay community is knowledgeable on the benefits of rubies. Characteristics that exist in the stone itself have been identified that this gem is a class of its own. The beliefs that Malay community has on rubies can be associated with local knowledge that exists about the gem are also discussed
\end{abstract}

\section{Introduction}

The Malay community is synonymous with the use of rubies as accessories, for example, rings. There are many types of precious stones such as Akik, Opal, Turquoise Stones, Jade, Amethysts, Pearls, Sapphire, Topaz, Emeralds and much more. Each and every stone mentioned possessing its own benefits and aura (Karyasa et al., 2015). Besides being exceptionally lovely, these precious stones are also being kept as special collections among the Malays (Gimlette, 1920). The influence that these stones portray has existed past decades (Ball, 1935) and the Malay community uses them in many different ways, such as medical. Apart from being used as accessories, these stones are also associated with the symbol of power, wealth, love and also zodiac (Ball, 1935). Generally, the Malay community uses precious stones as amulets to protect themselves from negative elements, such as devils and demons, to keep diseases at bay and also to maintain health (Gimlette, 1920). Merchants and businessmen are frequently seen to be selling the precious stones in places where the Malays dominantly visit such as night markets, expo, shopping complexes and so on.

Rubies are the focus of this study. Generally, rubies tend to be red in colour (Park et al., 2007; Ronald W. Arends, 2000). Many facts and beliefs among the community toward rubies. Rubies are widely known as a red colour, which is the symbol of love, power and pride. The title 'king of gemstone' was given to justify that this particular stone is famous not only among the Malays, but also throughout the world (Bank et al., 1988; Joseph, Lal, Shinde, \& Padalia, 2000; Park et al., 2007; Spiegehan, 2000). Rubies become synonymous with the Malays due to its physical beauty, aura and the benefits possessed. According to Flöter, Lujala, and Rød (2005), rubies are also in pink and dark red. The Mohs scaling ${ }^{1}$ of rubies is 9 and this proves that rubies are hard and strong (Joseph et al., 2000; Sioshansi, 1992). The best rubies are found in Myanmar (Bank et al., 1988) and good quality rubies are found in Tanzania, India, South Africa, Pakistan and Afghanistan. Rubies are assumed to be the birthstone for those born in the month of January and those who fall under the zodiac sign of Capricorn (Yeni Fitrianingsih, 2014).

\footnotetext{
${ }^{1}$ A scale of hardness used in classifying minerals. It runs from 1 to 10 using a series of reference minerals, and a position on the scale depends on the ability to scratch minerals rated lower.
} 


\section{Characteristics of Rubies}

Ruby, also known as red rubies, is a type of red stone and its colour ranges from light red to dark red (Kane, 1984). Rubies are a type of corundum minerals (A1203) (Calligaro, Poirot, \& Querré, 1999; Herman, 2008; Kane, 1984). Besides being physically attractive, rubies are also durable due to its high Mohs scale ${ }^{1}$ (9 to 10). The red on rubies is the effect of chromium element, which possesses a high content of aluminium oxide and crystal hexagonal material (Joseph et al., 2000; Stone \& Vickerman, 1971; Vickerman, 1971). The Malays named rubies as Delima due to the colour and shape which resembles pomegranates. The Malays regard rubies as one of the most precious stones beside sapphire, emerald and diamonds (Gimlette, 1920). The characteristics of popular rubies among Malays are presented in Table 1.

Table 1: The characteristics of popular rubies

\section{Delima Darah Merpati (Pigeon's Blood Rubies)}

It is known for dark red in colour with some infusion of blue. This precious stone has the highest value in the market with high demand.

\section{Delima Bintang (Star Rubies):}

Possess high quality and is able to reflect light. If the stone is projected with a light beam, this ruby is able to emit red light.

The price of the rubies is determined according to its colour. The most expensive and valuable stone should be sparkling in red (Ball, 1935). The clarity of rubies is also another characteristic, which determines its price and value among the Malays. Due to the close bond rubies share with the Malay community, certain beliefs and myths about this stone exist.

\section{Beliefs on the Benefits and Aura of Rubies in the Malay Community}

The Malay community believes that rubies have benefits and safeguards a person from threats such as black magic and from dignitaries and rulers. Individuals wearing rubies are said to be guarded against mystical disturbances. Rubies were worn by ancient Malay dignitaries due to Malay believes it could trigger majestic aura, whereby peasants and servants would dutifully obey, respect and bow to their commands (Gimlette, 1920).

The effects towards the servants would definitely be the ideal dream to the rulers in the sense that it will be easier for them to control and lead a group of people without any rebellion and dissatisfaction towards the leaders. Dignitaries in the old era not only used rubies in their rings but also pinned the stone into their kris. As for the merchants, they believe that rubies are able to bring benefits to their businesses. Owing to this fact, it is not surprising that most Malay merchants and businessmen possess much interest in owning ruby-stoned rings.

The Malay community believes that original and pure rubies are sanctified as this type of stone is associated with the mystical world. It is believed that a person who owns rubies are no ordinary individuals. It is supposed that for one to own rubies in the olden days will need to go through certain rituals and special ceremonies. Ancient Malay community, especially the Javanese Malay believed that rubies were originally genies which turned into a stone (Triyogo, 2005) and for one to possess a pure stone, the person needs to have a clean soul. If an owner would like to switch the possession to another person, it has to be voluntarily done without the involvement of money or other exchanges. Once sold, the rubies lose their benefits. The Javanese used to mention that owning rubies are usually fated and destined (Triyogo, 2005). The Malay community, especially in Indonesia, highly believes that anyone who owns authentic rubies will be invulnerable and impenetrable to sharp weapons (Triyogo, 2005). It is believed that no one can cut the hair or stab the skin of a person who wears a ring made from rubies. 


\section{Local Malay Intelligence on Rubies}

There is various local wisdom related to the rubies among the Malay community especially knowledge inherited from their ancestors (Gimlette, 1920). Firstly, rubies can be used in healing processes and medical purposes. There are a small group of Malays who still use rubies as a tool to heal diseases. For instance, sickness includes joint pain, cardiovascular diseases, nervousness, insomnia, sinusitis, high blood pressure, diabetes and many others. One way healing those diseases mentioned is through the use of rubies. The first method used in healing is by placing rubies in or around pain areas. In the second method, the rubies would be smashed into powder form to be consumed by patients. The former method treats external pain while the latter focuses on healing internal pain. It is also said that the presence of rubies alone may be able to protect an individual from getting ill. To maintain youngness and health, it is advised to soak rubies in a glass of plain water for about an hour and to drink the water thereafter. Authentic rubies will turn the plain water into the red.

Second wisdom is the methods to determine the real and high-quality rubies. A way to determine if the rubies are of high quality is by looking at the visual form of the stone. Stones of good quality can be seen to be having fibres or thin thread-like strands (Herman, 2008). There are some apparent differences between original rubies and synthetic ones. Fake rubies are appeared to be lighter than the original ones. In addition, real rubies are cooler when touched compared to the fake rubies, due to fake rubies are usually made from glass and other synthetic materials. Natural rubies are similar in size to pomegranate seeds, which is moderate in size. Another method to test the authenticity of rubies is to soak them in a glass of water. The water is then continued soak into another seven glasses of water and if the water still turns red colour, the rubies are considered pure and of high quality. The red colour of water would be visible for a one-month period. On the contrary, the red on synthetic rubies can easily fade as they contain phosphor. It is also said that a glass containing authentic rubies will be impenetrable even by bullets. The quality of rubies is also tested through their strength whereby an original piece will stay intact even when hammered. Besides, logics from Malay local intelligence suggest that natural and high-quality rubies may reach hundreds and thousands of ringgit in value. Any stone sold at a lower price may suggest that the rubies may not be original and are of low quality. However, this does not count in rubies which supposedly originate from the supernatural world that is prohibited from being sold.

Third, local intelligence on testing rubies that possess genies (Khadam). The term 'khadam' originates from the Arabic language which literally translates into a servant. In the context of local intelligence, these servants are known as a paranormal helper who lives in the supernatural world. The servants are frequently assumed to be genies. The existence of genies has been mentioned in the holy Quran. The servants are said to be creatures originating from the genies and angels (Kane, 1984). Theologians believe that the servants as mentioned in the holy Quran does not possess magical or supernatural powers as believed by certain Malay community and the idea that the servants residing in the rubies will make the stone magical has been brushed aside (Akhmad, 2013). The 'khadam' mentioned in the Quran relates more to the protective system allocated to those who are duly followers and with high faith in Islamic teaching.

"For each one is successive [angels] before and behind him who protect him by the decree of Allah. Indeed, Allah will not change the condition of a people until they change what is in themselves. When Allah intends for a people ill, there is no repelling it. And there is not for them besides Him any patron”. (QS. ar-Ra'd; 13/11)

The methods practiced by the Malay community in determining if a ruby possesses khadam as follow:

i. Free from impurities.

ii. Touch the ring using a right middle finger.

iii. The finger is then placed in the upper palate of the mouth.

iv. To recite the verse of An-Nas thrice with the eyes closed and pray with the intention to see the 'khadam'.

v. With the eyes still closed, place the thumb on the middle finger.

If the ruby possesses khadam, the following will happen:

i. Animal forms or colours will be visible

ii. Vibration and biting sensation will be felt on the middle finger 


\section{$5 \quad$ Discussion and Conclusion}

As a Muslim who believes in the teachings of Allah, an individual should surrender fully to the Almighty God. No living or non-living creatures in the world is able to provide benefits unless with His permission. For example, the use of precious stones as rings is not prohibited but the benefits and aura projected from the stones is to be believed to have come from the permission of Allah S.W.T.

There is definitely a meaning behind every creation of Allah S.W.T. Thinkers and the intelligent would definitely look beyond every creation and investigate the unique creations. Rubies or any other materials are gifts and reward from Allah S.W.T with their own characteristics and nature such as the sweetness of sugar and saltiness of salt. Precious stones such as rubies possess their own specific benefits and aura and only those knowledgeable and following the right path will be able to reap the benefits over the matters mentioned. The higher content of metal minerals in a stone, the higher would be the electromagnetic waves formed. The effect of these waves on the human body is known as an aura (Fitrianingsih, 2014).

One idea to understand is the awareness that no living or non-living entities possess supernatural powers. In this context, the benefits and advantages associated with rubies are given and permitted by Allah S.W.T. Overall, dependence towards Allah has to be practised for one not to fall under the category of 'syirik' (polytheistic or believing that there is more than one God).

\section{Acknowledgment}

Much appreciation is extended to the Ministry of Higher Education and Long-Term Research Grant Scheme (LRGS), (Local Knowledge) with the account number 203/PTS/6727002, USM members and those involved in this study.

\section{References}

1. Akhmad, P. (2013). Ilmu Hikmah Antara Hikmah Dan Kedok Perdukunan. Adamssein Media.

2. Ball, S. H. (1935). A historical study of precious stone valuation and prices. Economic Geology, 30(6), 630642. doi:10.2113/gsecongeo.30.6.630

3. Calligaro, T., Poirot, J. P., \& Querré, G. (1999). Trace element fingerprinting of jewellery rubies by external beam PIXE. Nuclear Instruments and Methods in Physics Research, Section B: Beam Interactions with Materials and Atoms, 150(1-4), 628-634. doi:10.1016/S0168-583X(98)01004-0

4. Flöter, A., Lujala, P., \& Rød, J. K. (2005). the Gemstone Dataset Codebook.

5. Gimlette, J. D. (1920). A Curious Kelantan Charm. Journal of the Straits Branch of the Royal Asiatic Society, $82,116-118$.

6. H. Bank, Gübelin, E., Harding, R. ., Henn, U., Scarratt, K., \& Schmetzer, K. (1988). An Unusual Ruby From Nepal. The Journal of Gemmology, 21(4), 222-226.

7. Herman, D. Z. (2008). Pendayagunaan mineral untuk menjadi permata. Museum Geologi, 5(7), 4-5.

8. Joseph, D., Lal, M., Shinde, P. S., \& Padalia, B. D. (2000). Characterization of gem stones ( rubies and sapphires ) by energy-dispersive x-ray fluorescence spectrometry. X-Ray Spectrometry, (May 1999), 147150. doi:10.1002/(SICI)1097-4539(200003/04)29:2<147::AID-XRS370>3.0.CO;2-K

9. Kane, R. E. (1984). Natural rubies with glass-filled cavities. Gems \&amp; Gemology, 187-189.

10. Karyasa, I. W., Dantes, I. G. R., Muderawan, I. W., Rai, I. W., Jasmani, J. P., \& Rekreasi, K. (2015). Geokimia Batu Permata Kresnadana Pulaki, 4(2), 604-610.

11. Park, G. S., Bae, S. C., Granick, S., Lee, J. H., Bae, S. D., Kim, T., \& Zuo, J. M. (2007). Naturally formed epitaxial diamond crystals in rubies. Diamond and Related Materials, 16(2), 397-400. doi:10.1016/j.diamond.2006.08.031

12. Ronald W. Arends. (2000). Enhanced Gem Stone And A Method Of Simulating The Appearance Of An Expensive Gem Stone. United State.

13. Sioshansi, P. (1992). Polishing process for refractory materials.

14. Spiegehan, J. M. (2000). A price above rubies: Patriarchy and the feminine. Psychological Perspectives, 40(1), 70-78. doi:10.1080/00332920008403369 
15. Stone, F., \& Vickerman, J. (1971). Magnetic properties of chromium ions in oxide matrices. Part 1. - Cr 2 O 3-Al 2 O 3 solid solutions. Transactions of the Faraday Society, 67, 316-328.

16. Triyogo, A. H. (2005). Benda-benda bertuah masyarakat Jawa. the University of Michigan: Narasi.

17. Vickerman, J. C. (1971). Magnetic properties of chromium ions in oxide matrices. Part 2.- $\mathrm{MgCr} 2 \mathrm{O} 4-$ MgAl2O4 solid solutions. Transactions of the Faraday Society, 67, 665-673.

18. Yeni Fitrianingsih. (2014). Pengaruh Hypnobirthing Terhadap Nilai Apgar Bayi Baru Lahir Pada Persalinan Normal Primipara. Universitas Diponegoro. 